\title{
Backsliding in Central and Eastern Europe
}

\section{Charles Gati *}

\section{Introduction}

Of the twenty-nine formerly Communist countries to have emerged from the former Soviet Union, Yugoslavia, and Eastern Europe, ten have navigated well the difficult passages of transition since the collapse of communism. These "leaders" are all in Central and Eastern Europe (CEE): Estonia, Latvia, and Lithuania in the Baltic region; Poland, the Czech Republic, Slovakia, Hungary, and Slovenia in Central Europe; and Romania and Bulgaria in South Eastern Europe. They have done well compared to such "laggards" as Croatia or Russia, and especially well compared to such "losers" in the transition as Kazakhstan or Turkmenistan. Today, the "Central European Ten" are all members of both NATO and the European Union; they all hold free, periodic elections (and those who lose invariably step aside); and, with a few exceptions, their economies, sparked by private capital, both domestic and foreign, have been growing far faster than those of their Western neighbors in the European Union. Indeed, the changes made are so substantial that the basic achievements of pluralism and the free market are not going to be reversed. The Central European Ten will avoid the abyss of Vladimir Putin's authoritarian Russia and muddle through, while such energetic countries as Slovenia and Estonia will continue to progress and catch up with their Western neighbors in the European Union in the next decade or so.

For the first time since the early 1990s, however, even the Central European Ten face growing and serious resistance to new and necessary political and economic reforms.

- In Poland, the new Polish government led by twin brothers Lech Kaczynski, the president, and Jaroslaw Kaczynski, the prime minister, concentrates less on deepening democratic reforms than on discrediting its opponents. Elected in late 2005, the government has shown immense hostility toward all political forces that have guided Poland's politics since 1989 and suspicion toward important parts of the outside world, notably Russia and Germany.

- In the Czech Republic, the atmosphere of hopeful optimism that flourished under President Vaclav Havel has given way to a political standoff that has prevented the rise of a workable parliamentary majority, and more generally to skepticism toward politics, an attitude exemplified by the policies and personality of President Vaclav Klaus.

\footnotetext{
Charles Gati is a Senior Adjunct Professor in the Nitze School of Advanced International Studies, Johns Hopkins University, Washington, D.C. This statement was prepared as testimony for the House Foreign Affairs Committee, and draws on an article co-authored by Charles Gati and Heather Conley, "Mission Unaccomplished: Backsliding in Central Europe,” International Herald Tribune (4 April 2007). Professor Gati is grateful to Ms. Conley for allowing him to incorporate parts of their longer draft into this essay.
} 
- In June 2006 in Slovakia, a coalition of three parties, of which two display the mentality of political authoritarianism, replaced Mikulas Dzurinda's government, which had engineered Slovakia's economic miracle in the previous few years. What happened, as the Financial Times noted, was "a popular backlash against ... Dzurinda's sweeping free-market reforms that [had] turned Slovakia from international pariah into a country championed by foreign investors."1

- In Hungary, the main right-wing opposition party, FIDESZ, having lost two consecutive elections, tried to seize power in the fall of 2006 via a series of demonstrations, some violent, some peaceful, while the country's socialist-led government resorted to the use of excessive force to protect its authority. Meanwhile, excessive government spending before the 2006 elections (which also entailed lying about economic conditions) seriously damaged an economy that was once the region's top performer. Probably in order to repair the damage, Hungary has sought to improve commercial ties with Russia, a process that could open the way not only to increased trade but also to Russian investments in strategic areas such as energy, electric works, and telecommunications.

Central Europe is thus experiencing a winter of discontent. ${ }^{2}$ Having joined NATO and the European Union, too, Bulgaria and especially Romania can ignore Brussels' advice without fearing a strong reaction. Elsewhere, populist or demagogic parties keep gaining adherents while other parties often feel compelled to compete with their empty rhetoric.

\section{Worrying Regional Trends}

Bluntly put, the region that the United States has held up as a model for democracyarguably the only region where democracy has taken root since the collapse of communism-is drifting away from the ambitious goals it set in 1989 and in the years that followed. Most disturbingly, Poland-now as always the barometer of change in Central and Eastern Europe-appears bent on undoing such major aspects of its postCommunist transformation as the compromises made by Solidarity-led anti-Commu-

1 Financial Times, (18 June 2006).

2 For more details, see F. Stephen Larrabee, "Danger and Opportunity in Eastern Europe," Foreign Affairs (November/December 2006); and Marian L. Tupy, The Rise of Populist Parties in Central Europe: Big Government, Corruption, and the Threat to Liberalism (Washington, D.C.: CATO Institute; November 2006). For an insightful perspective by a leading European scholar, see Jacques Rupnik, Populism in East-Central Europe, No. 94 (Vienna: Institute for Human Sciences, Fall 2006). The case against Poland's current government of President Lech Kaczynski and his twin brother, Prime Minister Jaroslaw Kaczynski, notably its campaign of lustration or purification, is made by Adam Michnik in "The Polish Witch-Hunt," The New York Review of Books 54:11 (28 June 2007). (An early statement on lustration is Jeri Laber, "Witch Hunt in Prague," The New York Review of Books 39:8 (23 April 1992)). For a different view that questions the significance of negative trends, see Janusz Bugajski, “Populist Piffle,” The Wall Street Journal (8 November 2006). 
nists in 1989 with the country's Communist authorities. In its 2007 issue of its annual report Nations in Transit (which every year includes a so-called "Democracy Score"), Freedom House has downgraded Poland from its No. 1 position in 1999 to being No. 8 in 2007. ${ }^{3}$ In Poland and elsewhere, several disturbing regional trends are in evidence, which will be outlined below.

\section{Populist Demagoguery}

The first of these worrying regional trends is a renewed, polarizing, at times vitriolic, and ultimately destabilizing campaign, particularly intense in Poland, against political opponents, notably ex-Communists and their liberal allies. For the past twenty months or so, the Kaczynski twins have unleashed a crusade against the uklad or "the arrangement.” Better understood as a conspiracy, uklad refers to a corrupt coalition of Communists and ex-Communists, businessmen, secular liberals, survivors or remnants of the old secret police, and Russians who (it is claimed) have undermined Poland's moral authority and values. It is this coalition, real or imagined, that the Polish government seeks to expose and destroy.

The popular appeal of exposing uklad stems, in part, from the traditional place conspiracies have long had in the region's political cultures; for some, conspiracies still offer easy answers to difficult dilemmas about why things are not better than they are. More immediately, and perhaps more importantly, there is an almost universal and fully understandable revulsion in Poland (and elsewhere) against corruption, which has seriously damaged the reputation of both the economic and the political elites. Riding on this wave of widespread public indignation, the Kaczynski twins, who are not known to have engaged in shady practices, have made the fight against corruption the centerpiece of their administration.

Yet, after almost two years in power, no major arrests or convictions for corruption have taken place. The most celebrated "success" so far has been the dissolution of the Polish military intelligence service earlier this year, a process directed by a certain Antoni Macierewicz, a close friend of the Kaczynskis and a particularly agitated farright radical. The problem with his case was not only weak evidence-some of those he accused of collaborating with the Communists were children or teenagers in 1989but also Macierewicz's own curious past that in his youth included admiration for Che Guevara and in the 1990s opposition to Poland's membership in the European Union. Moreover, he has been a leading light on Radio Maryja, known for its promotion of

3 "Democracy Score" is identified in "Selected Data and Polls from Central and Eastern Europe," at the end of this essay. 
right-wing conspiracy theories and anti-Semitic innuendos. ${ }^{4}$ Someone with a more consistent past might have credibly pursued such a purge; after all, the basic idea of exposing economic and political corruption was fully justified and urgently needed.

There is an inner circle around the Kaczynski brothers who believe that the 1989 roundtable that set Poland on a peaceful rather than a violent path of transition was wrong and thus what Poland has experienced is an unfinished revolution; this group also appears to believe that a permanent revolution is now needed to undo the damage. ${ }^{5}$ This is why the composition of the Polish government keeps changing. Few are trusted; almost everyone is suspect. During its less than twenty months in power, the government initially ruled as a minority government; then it made a deal with a demagogic left-wing party (Self-Defense) and a demagogic right-wing party (League of Polish Families); then it excluded the leftists but soon returned them to the coalition; and then, in mid-July of 2007, the leftists left again, but might still return to assure the Kaczynskis' parliamentary majority. Some may argue, of course, that this is "Italian politics on the Vistula”; others may conclude, however, that, given Poland's relatively fragile democratic culture, the Kaczynski brothers' stubborn intolerance may damage the quality of Polish political life.

Meanwhile, the Kaczynski government has had no fewer than five finance ministers, two foreign ministers, two defense ministers, and even two prime ministers. The country's diplomatic service has been decimated. The personnel of the Office of National Remembrance, where many of the old files are housed, have been purged. The constant flux of leading personalities is as harmful as it is mystifying. Are the Kaczynski brothers-who concentrate so much power in their own hands-crusading radicals, or are they merely inexperienced or incompetent? The polls appear to suggest radicalism rather than inexperience as the primary reason for their political performance. The majority of the Polish people-some 70 percent—believe that the random opening of old Communist files is meant to distract attention from other issues facing their country.

True or not, the ongoing, desperate search for culprits (or scapegoats) has produced deep divisions in the region's politics, turning even family members against one another. In an atmosphere of "if you're not with us, you're against us," these polarized

4 Macierewicz himself has written that Poland regained independence in 1989 "after 50 years (sic) of occupation directed by communists of Jewish origin supporting Russian Bolshevism.” Antoni Macierewicz, “The Revolution of Nihilism,” Glos (3 February 2001); available at http://wiez.free.ngo.pl/jedwabne/article/26.html. In fact, while Jews played a prominent role in the Communist movement in Poland and elsewhere (notably in Romania and Hungary), none of the general secretaries or first secretaries of the Polish Communist Party after World War II is known to have been of "Jewish origin."

5 This mentality is also present in other countries of the region, such as the Baltic states, the Czech Republic, as well as in FIDESZ, the Hungarian opposition party. Proponents of this view, as in Poland, usually call themselves conservatives (and in some respects they are), but they are radicals when they pursue what amounts to a "permanent revolution" against the compromises worked out in 1989. 
polities feature sharp categories of good vs. evil, a state of discourse that harms such critical elements of democratic political life as tolerance and civility and thus the ability to compromise.

\section{A Leadership Vacuum}

The second trend that has become increasingly evident in recent months and years is the region's leadership deficit. The comparison with the 1990s is especially clear. In the Czech Republic, there was Vaclav Havel. Poland offered Lech Walesa, Tadeusz Mazowieczki, and Bronislaw Geremek. In Hungary, there was Jozsef Antall and Arpad Goncz. In the Baltic states, such dedicated men and women as Lithuania's Valdas Adamkus, Latvia's Vaira Vike-Freiberga, and Estonia's Lennart Meri paved the way to their countries' integration into Euro-Atlantic institutions. While they did not share the same political philosophy_some were conservative and some liberal, some religious and some secular, some fervently nationalist and some strongly integrationist—-they all worked hard to ally their countries with the United States and Western Europe, and they showed a good deal of tolerance toward their political opponents.

By contrast, such principled and visionary leaders articulating national needs, interests, and aspirations are now in short supply. Many (and perhaps most) of those in prominent positions today are pragmatic politicians seemingly interested only in gaining and holding on to power. They are not necessarily worse than their counterparts in Western Europe or elsewhere in the world; it is only that, given their predecessors' reputations and commitment to their causes, the current generation's negative qualities are now more evident.

The reasons for the region's leadership deficit are hard to identify. It may be that, having achieved membership in NATO and the European Union, it is more difficult now to pursue high-minded and ambitious goals. More likely, demagogic leaders find it politically advantageous to seek and obtain support from large minorities-in some cases, majorities - that have not benefited sufficiently from the post-1989 changes: these are the "losers" who see themselves as victims of still another political and economic order that has failed to meet their needs. Of course, such people and groups tend to favor politicians who offer easy solutions. This is why Robert Fico rather than Mikulas Dzurinda is Slovakia's prime minister. This is why even Vaclav Havel has lost his appeal to most of his countrymen in the Czech Republic. In today's Central and Eastern Europe, the era of leaders asking for blood, sweat, and tears is over - and aspiring politicians know it.

\section{Resistance to Reform}

The third trend is popular resistance to the next round of economic reforms. In retrospect, the extraordinary economic transformation achieved in the 1990s, which included privatization and currency stabilization, among others, was easy going compared to what several of the region's governments are now attempting to do or should be doing-i.e., privatize parts of health care and higher education so as to rationalize these services and limit government subsidization. The problem is that people who are used to "free" health care and "free" education oppose the introduction of such re- 
forms. They are nostalgic for the meager benefits of the welfare state, preferring to listen to the siren song of populist politicians who promise a better life without additional taxes or fees and without pain. This is true even if populist politicians, such as Slovakia's Robert Fico, may not reverse their predecessors' policies once they are in power. The political axiom often prevails: where you sit is where you stand.

Stated simply, after more than fifteen years of reforms and experimentation, capitalism itself is not doing so well in Central and Eastern Europe. True, there is no alternative to the free market; it is, indeed, the worst economic system except for all the others, which are worse. But, to repeat, too many people have yet to benefit economically from the new order. Shortages are a thing of the past-but who can afford all the expensive items displayed in elegant stores? Walking the beautiful downtown areas of Prague or Budapest, it is easy to believe that all is well, but there is a huge, and growing, gap throughout the region between city and countryside. This gap is one of the sources of social tension and polarization, for the region's dominant political parties have yet to find the proper balance between offering incentives to the entrepreneurial middle class and at the same time offering a meaningful social contract to wage-earners and the unemployed. To win elections, the region's political parties must appeal to the energetic, city-based middle class, which is eager to favor public policies that create new opportunities. Yet the same political parties must also appeal to the entirely different mindset of the rural population, which is interested in greater social spending and a vague return to traditional values. Alas, more often than not these interests and visions are incompatible.

Finally, there is a growing gap in some of the countries of the Central European Ten between rich and poor that is an important source of pervasive skepticism about the merits of capitalism. According to a European Union survey of all of Europe, the gap between incomes of the top 20 percent of the population and the bottom 20 percent is greatest in Portugal-but Poland, Latvia, and Lithuania are not far behind. (Such wealthy but more egalitarian countries as Germany and France are far behind.) The Polish income ratio between the rich and the poor is more than 40 percent higher than in the average European Union member state. For a striking comparison, Poland can be said to be 100 percent more unequal than Sweden and 60 percent more unequal than Germany. The paradox that has come to prevail today is therefore this: Large segments of the region's populations know that pre-1989 "socialism" did not work, and they know it could not be resurrected anyway, but in their dislike for income differentiation under capitalism they favor populist politicians who spout egalitarian rhetoric.

\section{The Changing International Arena}

The fourth trend is the ongoing radical transformation of Central and Eastern Europe's international environment. The historical comparison is striking: in 1989 and throughout the 1990s, all of the countries of Central and Eastern Europe turned to Washington for guidance. They understood and appreciated the significance and benefits of the Atlantic Alliance. They all sought to join NATO, in part because it was a Western alliance and membership signified their return to "the West." They also wanted to join NATO in order to protect themselves against a possible revival of Russian ambitions. 
For these reasons and more, the United States (as NATO's leading power) was, for all of Central and Eastern Europe, the country of hope, the assurance that the single most important goal of their 1989 peaceful revolutions-independence-would be achieved and defended. Put another way, the United States, having won the Cold War against the much-despised Soviet Union, could do no wrong at that time. It is only a slight exaggeration to suggest that when American diplomats made a request to a Central or Eastern European government in the 1990s, they did not have to ask twice.

The European Union also generated a good deal of interest in the 1990s. The hope that these former Communist countries could soon "return to Europe" after decades of enforced subservience to the Soviet Union was both widely and deeply held. If the U.S. role was to protect the region's independence, the European Union's role was to help move Central and Eastern Europe from the continent's economic periphery to its center-and prosperity would follow. The slow pace of the admission process disappointed some, but by the end of the decade there was hope once again of membership in this exclusive European club.

Russia, for all practical purposes, was not a player in Central and Eastern Europe in the 1990s. It mourned the loss of its "external empire" as it focused, unsuccessfully, on protecting its real or imagined interests in the "internal empire" in the former Soviet Union itself. Beyond a few gestures under President Boris Yeltsin, Russia had little or nothing to offer to its former Warsaw Pact satellites (it was even too poor to buy Bulgarian tomatoes or Hungarian salami). An occasional news item about mischief by Russian secret services, notably in the Baltic states, with their large Russian ethnic populations or in Poland, reminded the world of Moscow's old ways, but Russia had neither the economic nor the political means by which to influence in any significant fashion the course of events in Central and Eastern Europe.

In 2007, the region's international environment is different. Despite dramatically declining public support for U.S. policies in the Middle East and elsewhere, the Central European Ten still favor close relations with the United States. Of the ten, Estonia, Latvia, Lithuania, Poland, and to a lesser extent Romania and the Czech Republic have governments that continue to seek and value American protection against a revived Russia under President Vladimir Putin. To some extent, the other four-Slovakia, Hungary, Slovenia, and Bulgaria — also cooperate with Washington on such issues as fighting terrorism (and, earlier, even on Iraq), drug interdiction, etc., but in these countries there is far less interest in maintaining strong ties with the United States. A new generation there, and indeed throughout the region, does not seem to appreciate what the United States did to save Europe from the Nazis and from the Soviet Union. What they know is what Washington is doing in Iraq; what they know is Washington's unwillingness to pave the way to visa-free travel; and what they know is the gap between Washington's verbal promotion of democracy and the absence of deeds to back it up - that is, the absence of a genuine relationship between ends and means that used to enhance America's presence, credibility, and reputation in the region in the 1990s.

The polling data appended to this essay speak for themselves. Particularly striking is the drop in Polish public approval of U.S. policies-from 62 to 38 percent in one year-because Poland used to be the most pro-American country in the world. The 
predominant attitude now is one of opposition to U.S. leadership in the world. Contrary to the received wisdom about "New Europe" being fundamentally different from "Old Europe," a more accurate formulation is that the United States has lost the high moral ground in every European country, from Great Britain to Turkey. All the same, those who fear Vladimir Putin's Russia most - the three Baltic states, Poland, and to a lesser extent Romania and the Czech Republic - continue to court and count on the United States.

Meanwhile, the European Union is riding high in Central and Eastern Europe. For a variety of projects, it is expected to provide Poland some USD 75 billion in the next seven years. Others may be benefiting less from membership, but they all have visafree travel in the EU area, increasingly good access to institutions of higher learning, and significant employment opportunities. (Presently, 1.5 million Poles work in Ireland, England, and elsewhere.) Throughout the region, all can see a national flag and the EU flag flying high-together! The best news from Central and Eastern Europe now is that integration has begun to work. Nationalist resistance is much weaker than it was even a year or two ago. Some of the most vocal Euro-skeptics have changed their tune and present themselves as supporters of their countries' association with the European Union. While, after decades of foreign oppression, it is hard to give up even a modicum of independence to an international body - even when it is done voluntarily!-the successful integration of the Central European Ten into larger European structures is under way. Today, the European Union has certainly taken the upper hand in the competition between the EU and the U.S.

Compared to the 1990s, Russia has a presence in the region now, and it is not a benevolent one, but its significance should not be overestimated. Russia offers energyoil and especially gas - to the Europeans, and it has made as many as ten bilateral deals with individual countries, rather than just one with the EU. The reasons for that approach are obvious. Moscow can make more money this way, and it can try to drive a wedge among European Union members by playing off one against the other. Gazprom and President Putin work hand in hand to spoil a common European energy "plan" (not common energy "policies," because such do not yet exist). This is why the Hungarian and Austrian dithering about the EU's Nabucco Project-a competitor to Gazpromwas unfortunate, but certainly not decisive. The issue of diversification is on the table, and all European governments would prefer not to have to rely on Russian energy alone.

Energy aside, Russia can offer its vast market for goods from the Central European Ten. How long, and how much, however, are the important questions to be raised in this regard. Of all the stock markets in the world, only one-Russia's—came down during the first half of 2007. This is bad omen for an economy that has grown but has not been modernized. Could it be that Russia, after impressive growth for several years that has been based only on the exploitation of vast energy resources, is facing its own diversification problem? Will it continue to grow even if it proves unable to develop new industries and new technologies, or if the price of energy finally comes down? Ultimately an economic dwarf rather than an economic giant, Russia, in the long run, has little to offer to Europe, including the Central and Eastern Europeans. 


\section{The United States' Role in Central Europe}

Thinking of policies that would strengthen the U.S. position in the region, it should be emphasized that for many years the United States will not recover the ground it has lost since the end of the 1990s. The time when U.S. diplomats could always and easily get what they want is over.

True, the Czech Republic and Poland, despite significant and perhaps decisive parliamentary opposition, are apparently ready to offer hospitality to new U.S. missile sites, which signals at least residual support for American strategic objectives. Yet as governments come and go, it is important to look ahead and pay attention to the region's publics, which have become increasingly critical of U.S. policies abroad and violations of democratic norms at home, and therefore no longer side automatically with the United States. In the longer run, they are unlikely to support governments that favor protection of the United States (and, in Washington's view, of Europe) by an untested American shield against a potential threat ten years or more from now over Russia's direct and more immediate threat to their own security. Indeed, Washington's reportedly rather heavy-handed demands for Polish and Czech cooperation may eventually weaken rather than strengthen America's position there. Thus, as these prospective missile sites actually make Poland and the Czech Republic more insecure, it would make good sense to delay their deployment, certainly not in order to appease Moscow but in order to dampen the fires of political polarization in these allied countries.

In the non-military realm, there are a few modest steps Washington could take. First, with help from Congress, the Department of State should reinstate some of the relatively inexpensive educational and cultural programs that until a few years ago used to advance the United States' good name in the region. Relatedly, the State Department should encourage U.S. businesses to offer seasonal summer jobs to young Central and Eastern Europeans. At various resorts, such as those on North Carolina's Outer Banks, many young Poles, Slovaks, Russians, and others now work for supermarkets, improving their knowledge of English and gaining insights into the American way of life. Why not extend such programs so that more young people from the region could see the U.S. as it really is? This is an area where the United States can compete with members of the European Union.

Second, Congress should urgently extend visa-free travel to citizens of the Central Eastern European Ten (as it presently does to older members of the European Union). If this had been done three or four years ago, America's image in the region would have been significantly advanced. As it is, with visa-free travel to the EU countries as well as increasing work and study opportunities there, the issue of entry to the U.S. has lost some of its initial import. Still, this would be a desirable and long overdue measure for Congress to enact.

Third, at a time when Washington has few effective instruments of policy at its disposal to make a difference in Central and Eastern Europe, it would serve U.S. interests to send a larger number of professional diplomats to the region. True, politically wellconnected ambassadors assigned to the capitals of the Central European Ten can and have made substantial contributions; being familiar with key players in Washington is 
useful. On the other hand, sending people with only minimal understanding of the local political and economic scene and especially of the region's turbulent past is a serious handicap. Meanwhile, rotating well-trained experts in Central and Eastern Europe to faraway lands about which they know little or nothing further complicates the increasingly difficult task of competent representation.

It may be that Washington's main problem is not only a shortage of means - that U.S. libraries in the region are closed, that the Department of State cannot bring future leaders to the U.S., that there are no funds for making the United States better known and respected. Nor can declining U.S. influence be blamed only on the Bush Administration's misplaced priorities and imprudent foreign policy. The additional problem is the tendency to take this region for granted, and to look for new "opportunities" on the assumption that "democracy promotion" will produce results around the globe. This is a mistaken assumption. Democracy does not fall on fertile soil everywhere. Even in Central and Eastern Europe it requires careful and generous cultivation.

\section{Selected Data and Polls from Central and Eastern Europe}

I. CIA World Factbook, 2007

GDP/Capita (2006 estimates)

\begin{tabular}{ll}
\hline Slovenia & $\$ 23,400$ \\
Czech Republic & $\$ 21,900$ \\
Estonia & $\$ 20,300$ \\
Slovakia & $\$ 18,200$ \\
Hungary & $\$ 17,600$ \\
Latvia & $\$ 16,000$ \\
Lithuania & $\$ 15,300$ \\
Poland & $\$ 14,300$ \\
Bulgaria & $\$ 10,700$ \\
Romania & $\$ 9,100$ \\
\hline
\end{tabular}

Average (countries, not population): \$18,375

European Union (27): \$29,900

II. Freedom House, Nations in Transit, 2007 (2006 in parenthesis)

A) "Democracy Score” (represents an average of seven subcategory ratings for electoral process; civil society; independent media; national democratic governance; local democratic governance; judicial framework and independence; and corruption. On a scale of 1 to 7, 1 represents the highest level of democratic development and 7 the lowest) 


\begin{tabular}{lll}
\hline & 2007 & 2006 \\
\hline Slovenia & 1.82 & $(1.75)$ \\
Estonia & 1.96 & $(1.96)$ \\
Latvia & 2.07 & $(2.07)$ \\
Slovakia & 2.14 & $(1.96)$ \\
Hungary & 2.14 & $(2.00)$ \\
Czech Republic & 2.25 & $(2.25)$ \\
Lithuania & 2.29 & $(2.21)$ \\
Poland & 2.36 & $(2.14)$ \\
\hline
\end{tabular}

B) Corruption

\begin{tabular}{lccc}
\hline & 2007 & 2006 & 2005 \\
\hline Slovenia & 2.25 & 2.25 & 2.00 \\
Estonia & 2.50 & 2.50 & 2.50 \\
Hungary & 3.00 & 3.00 & 2.75 \\
Poland & 3.00 & 3.25 & 3.00 \\
Latvia & 3.00 & 3.25 & 3.50 \\
Slovakia & 3.25 & 3.00 & 3.00 \\
Czech Republic & 3.50 & 3.50 & 3.50 \\
Bulgaria & 3.75 & 3.75 & 4.00 \\
Lithuania & 4.00 & 4.00 & 3.75 \\
Romania & 4.00 & 4.25 & 4.25 \\
\hline
\end{tabular}

III. Transparency International, 2006 (TI Corruption Perception Index)

Least corrupt: Finland, Iceland, New Zealand - CPI Score: 9.6

Most corrupt: Haiti, 1.8

163 countries surveyed

20. Belgium, Chile, USA

24. Barbados, Estonia

6.7

28. Malta, Slovenia, Uruguay

6.4

41. Hungary

5.2

46. Czech Republic, Kuwait, Lithuania

4.8

49. Latvia, Slovakia

4.7

57. Bulgaria, El Salvador

4.0

61. Jamaica, Poland

84. Romania, Algeria, Madagascar, Mauritania, Sri Lanka

IV. Eurobarometer, 2007

A) How would you judge your country's economy? 
THE QUARTERLY JOURNAL

"Very good \& rather good"

\begin{tabular}{ll}
\hline Denmark & $99 \%$ \\
European Union (27) & $52 \%$ \\
Estonia & $81 \%$ \\
Slovenia & $72 \%$ \\
Slovakia & $55 \%$ \\
Czech Republic & $45 \%$ \\
Poland & $45 \%$ \\
Lithuania & $33 \%$ \\
Latvia & $22 \%$ \\
Romania & $18 \%$ \\
Bulgaria & $10 \%$ \\
Hungary & $9 \%$ \\
\hline
\end{tabular}

B) Is membership in the EU a good thing?

\begin{tabular}{ll}
\hline The Netherlands & $77 \%$ \\
European Union (27) & $57 \%$ \\
Poland & $67 \%$ \\
Romania & $67 \%$ \\
Estonia & $66 \%$ \\
Slovakia & $64 \%$ \\
Lithuania & $63 \%$ \\
Slovenia & $58 \%$ \\
Bulgaria & $56 \%$ \\
Czech Republic & $46 \%$ \\
Hungary & $37 \%$ \\
Latvia & $37 \%$ \\
\hline & \\
C) Are you very optimistic/fairly optimistic & \\
\hline European Union (27) & $69 \%$ \\
Poland & $82 \%$ \\
Slovenia & $80 \%$ \\
Estonia & $77 \%$ \\
Slovakia & $75 \%$ \\
Romania & $75 \%$ \\
Lithuania & $74 \%$ \\
Czech Republic & $66 \%$ \\
Bulgaria & $66 \%$ \\
Latvia & $60 \%$ \\
Hungary & $58 \%$ \\
\hline
\end{tabular}


D) Comparison of polls taken within the Central European Ten comparing opinion on the U.S. with that on the EU regarding world peace

Adapted from Eurobarometer September 2005, with polling taking place between May and June 2005

\begin{tabular}{lcc}
\hline & $\begin{array}{c}\text { In your opinion, would you } \\
\text { say that the US tends to play } \\
\text { a positive role regarding } \\
\text { peace in the world? }\end{array}$ & $\begin{array}{c}\text { In your opinion, would you } \\
\text { say that the EU tends to play } \\
\text { a positive role regarding } \\
\text { peace in the world? }\end{array}$ \\
\hline Bulgaria & $24 \%$ & $74 \%$ \\
Czech Republic & $43 \%$ & $80 \%$ \\
Estonia & $30 \%$ & $76 \%$ \\
Hungary & $30 \%$ & $72 \%$ \\
Latvia & $30 \%$ & $70 \%$ \\
Lithuania & $49 \%$ & $78 \%$ \\
Poland & $33 \%$ & $63 \%$ \\
Romania & $57 \%$ & $81 \%$ \\
Slovakia & $34 \%$ & $79 \%$ \\
Slovenia & $18 \%$ & $73 \%$ \\
Central European & $35 \%$ & $75 \%$ \\
Ten (average) & &
\end{tabular}

\section{German Marshall Fund, Transatlantic Trends, 2006}

A) How desirable is it that the U.S. exerts strong leadership in world affairs?

"Very desirable \& somewhat desirable"

\begin{tabular}{ll}
\hline Europe 12 & $35 \%$ \\
United States & $84 \%$ \\
Poland & $39 \%$ \\
Slovakia & $19 \%$ \\
Bulgaria & $21 \%$ \\
Romania & $46 \%$ \\
\hline
\end{tabular}

B) How desirable is it that the EU exerts strong leadership in world affairs?

"Very desirable \& somewhat desirable"

\begin{tabular}{ll}
\hline EU 12 & $70 \%$ \\
United States & $76 \%$ \\
Poland & $70 \%$ \\
Slovakia & $50 \%$ \\
Bulgaria & $55 \%$ \\
Romania & $65 \%$ \\
\hline
\end{tabular}


C) Do you approve or disapprove of the way the President of the U.S. is handling international politics?

“Approve very much \& approve somewhat”

\begin{tabular}{ll}
\hline Europe 12 & $18 \%$ \\
United States & $40 \%$ \\
Poland & $41 \% *$ \\
Slovakia & $23 \%$ \\
Bulgaria & $20 \%$ \\
Romania & $41 \%$ \\
\hline
\end{tabular}

*Poland: Approve very much: 3\%; somewhat: 38\%

VI. BBC Poll on U.S. Role in the World, 2006-2007 (selected European countries)

A) "Views of U.S. influence mainly positive":

\begin{tabular}{ll}
\hline France & $24 \%$ \\
Germany & $16 \%$ \\
Great Britain & $33 \%$ \\
Italy & $35 \%$ \\
Portugal & $38 \%$ \\
Russia & $19 \%$ \\
Turkey & $7 \%$ \\
Poland & $38 \%$ (dropped from $62 \%$ in one year) \\
Hungary & $29 \%$ \\
\hline
\end{tabular}

Average in 18 countries polled:

2005: $40 \%$

2006: $36 \%$

2007: $29 \%$

B) Handling Iraq by U.S.: "Strongly" or "somewhat approve":

\begin{tabular}{lr}
\hline France & $5 \%$ \\
Germany & $11 \%$ \\
Great Britain & $13 \%$ \\
Italy & $15 \%$ \\
Portugal & $16 \%$ \\
Russia & $5 \%$ \\
Turkey & $6 \%$ \\
Poland & $22 \%$ \\
Hungary & $12 \%$ \\
\hline
\end{tabular}




\section{Bibliography}

Bugajski, Janusz. "Populist Piffle." The Wall Street Journal (2006).

F. Larrabee, Stephen. "Danger and Opportunity in Eastern Europe." Foreign Affairs 85, no. 6 (2006).

Macierewicz, Antoni. "The Revolution of Nihilism." Glos (2001).

Michnik, Adam. "The Polish Witch-Hunt." The New York Review of Books 54, no. 11 (2007).

Rupnik, Jacques. Populism in East-Central Europe. Vienna: Institute for Human Sciences, 2006.

Tupy, Marian L.. The Rise of Populist Parties in Central Europe: Big Government, Corruption, and the Threat to Liberalism. Washington, D.C.: CATO Institute, 2006. 